\title{
Role of Mas receptor antagonist (A779) in renal hemodynamics in condition of blocked angiotensin II receptors in rats
}

\author{
A Mansoori ${ }^{1,2}$, S Oryan ${ }^{2}$, M Nematbakhsh ${ }^{1,3}$ \\ ${ }^{1}$ Water and Electrolytes Research Center, Isfahan University of Medical Sciences, Isfahan, Iran \\ ${ }^{2}$ Department of Biology, University of Kharazmi, Tehran, Iran \\ ${ }^{3}$ Isfahan MN Institute of Basic and Applied Sciences Research, Isfahan, Iran
}

Received: January 21, 2014

Accepted: September 3, 2015

\begin{abstract}
The vasodilatory effect of angiotensin 1-7 (Ang 1-7) is exerted in the vascular bed via Mas receptor (MasR) gender dependently. However, the crosstalk between MasR and angiotensin II (Ang II) types 1 and 2 receptors (AT1R and AT2R) may change some actions of Ang 1-7 in renal circulation. In this study by blocking AT1R and AT2R, the role of MasR in kidney hemodynamics was described. In anaesthetized male and female Wistar rats, the effects of saline as vehicle and MasR blockade (A779) were tested on mean arterial pressure (MAP), renal perfusion pressure (RPP), renal blood flow (RBF), and renal vascular resistance (RVR) when both AT1R and AT2R were blocked by losartan and PD123319, respectively. In male rats, when AT1R and AT2R were blocked, there was a tendency for the increase in $\mathrm{RBF} /$ wet kidney tissue weight $(\mathrm{RBF} / \mathrm{KW})$ to be elevated by $\mathrm{A} 779$ as compared with the vehicle $(\mathrm{P}=0.08)$, and this was not the case in female rats. The impact of MasR on renal hemodynamics appears not to be sexual dimorphism either when Ang II receptors were blocked. It seems that co-blockade of all AT1R, AT2R, and MasR may alter RBF/ $\mathrm{KW}$ in male more than in female rats. These findings support a crosstalk between MasR and Ang II receptors in renal circulation.
\end{abstract}

Keywords: renin angiotensin system (RAS), angiotensin (1-7) receptor, angiotensin type 1 and 2 receptors, renal blood flow

The morbidity and progression of many renal diseases are gender related $(26,34)$. The mechanisms underlying this difference are not clearly recognized, but it is at least understood that renin-angiotensin system (RAS) is involved (14). RAS has a major role in kidney function, and it regulates the body fluid and blood pressure gender dependently $(8,13,37)$. RAS includes vasoconstriction and vasodilation effects in renal and systematic vascular bed depending on the angiotensin converting enzyme 1 and 2 (ACE or ACE1, ACE2) (32, 43). ACE hydrolyzes angiotensin (Ang) I to Ang II, while ACE2 disintegrates Ang II to Ang 1-7 and Ang I to Ang 1-9 (11, 12, 36, 41). It is known that the physiological actions of Ang 1-7 are exerted via Mas receptor (MasR) $(18,31,42)$. The two main receptors of Ang II are Ang receptors types 1 and 2 (AT1R and AT2R). AT1R causes vasoconstriction, cell multiplication, and sodium retention. It also attenuates glomerular filtration rate as well as it augments mesangial cell hypertrophy and renal damage, while AT2R and MasR disagrees with the AT1R functions $(35,40)$. It is reported that MasR is an AT1R antagonist and Ang 1-7/ MasR

Corresponding author: Mehdi Nematbakhsh, $\mathrm{PhD}$

Water and Electrolytes Research Center/Department of Physiology, Isfahan University of Medical Sciences and Isfahan MN Institute of Basic and Applied Sciences Research, Isfahan, Iran

Phone: +98-31-37929019; Fax: +98-31-37929019; E-mails: nematbakhsh@med.mui.ac.ir; nematbakhsh@gmail.com 
straightly resists many actions of Ang II (38). The role of Ang 1-7 in cardiovascular system has been studied; however, the exact mechanism is not completely understood (17). In addition, blockade of AT1R and AT2R also inhibits some actions of Ang 1-7, which indicates a crosstalk between MasR and Ang II receptors (4, 6, 20, 45). Moreover, increase in nitric oxide (NO), bradykinin, and prostacyclin production complicates the mechanism of Ang 1-7 action (3). It was also explained that the vasodilator effect of Ang 1-7 complicates the interaction of MasR with AT1R and AT2R in perfused mouse heart (7). Females have AT2R/ AT1R ratio higher than males (35), but MasR blockade or knockout of ACE2 can abolish sex difference in response to Ang II infusion in rats (38). Administration of MasR antagonist (A779) in female rats also equals the blood pressure response to Ang II in both genders (38). This shows the complex interactions between the RAS receptors and vascular effect of Ang 1-7 (23). Recently, it has been explained that expression of renal MasR is higher in adult female than male rats (29), and Safari et al. have demonstrated that presence of MasR in female rats increases renal blood flow (RBF) following physiological situation and decreases renal vasoconstrictor response to exogenous Ang II infusion (27). In the present study, AT1R and AT2R were blocked using losartan and PD123319 in male and female rats and the RBF and RVR were measured with and without MasR antagonist (A779).

\section{Materials and Methods}

\section{Animals}

Male $(\mathrm{n}=27,190 \pm 2.3 \mathrm{~g})$ and female $(\mathrm{n}=22,180 \pm 1.0 \mathrm{~g})$ Wistar rats (Animal Centre, Isfahan University of Medical Sciences) were used. The rats were individually housed at a temperature of $23-25^{\circ} \mathrm{C}$ with a $12 \mathrm{~h}$ light/dark cycle (darkness $19.00-07.00 \mathrm{~h}$ ). The experimental procedures were in advance approved by the Isfahan University of Medical Sciences (\#191066).

\section{Surgery}

Rats were anaesthetised (Inactin; thiobutabarbital, $175 \mathrm{mg} \mathrm{kg}^{-1}$ i.p. Sigma, St. Louis, MO, USA) and the trachea was subjected to insert air ventilation tube. Catheters were implanted into the jugular vein, and carotid and femoral arteries. Renal perfusion pressure (RPP) was measured from the femoral artery. The left kidney was placed in a stable cup. The flow probe was placed and fixed around the left renal artery, and renal blood flow (RBF) was measured by transit-time ultrasound flowmetry (Type 2SB; transonic system, Itaca, NY, USA). Body temperature was continuously monitored through the experiment. 30-60 minutes was allowed for equilibration period.

\section{Experimental protocol}

Losartan (Darou Pakhsh Pharma Co., Tehran, Iran), PD123319 (Sigma, St. Louis, MO, USA), and A779 (Bachem Bioscience Inc., King of Prussia, PA, USA) were used as blocking agents for AT1R, AT2R, and MasR, respectively. After the equilibration period (30-60 min), male or female rats received losartan $\left(10 \mathrm{mg} \mathrm{kg}^{-1}\right.$ plus $\left.10 \mathrm{mg} \mathrm{kg}^{-1} \mathrm{~h}^{-1}\right)$ (17), PD123319 ( $1 \mathrm{mg} \mathrm{kg}^{-1}$ plus $1 \mathrm{mg} \mathrm{kg}^{-1} \mathrm{~h}^{-1}$ ), and A779 (50 $\mathrm{g} \mathrm{kg}^{-1}$ plus $\left.50 \mu \mathrm{g} \mathrm{kg}^{-1} \mathrm{~h}^{-1}\right)$ (33), and they were compared with the groups that received the same antagonists except vehicle $\left(2 \mathrm{ml} \mathrm{kg}^{-1}\right.$ plus $2 \mathrm{ml} \mathrm{kg}^{-1} \mathrm{~h}^{-1} 154 \mathrm{mmol} \mathrm{l}^{-1} \mathrm{NaCl}$ ) instead of A779. Therefore for each gender, two main 
groups were assigned; group 1 treated with losartan, PD123319, and A779, and group 2 treated with losartan, PD123319, and vehicle. The time before commencing the vehicle or antagonist administration was considered as the control time, and the time $30 \mathrm{~min}$ after commencing vehicle or antagonist administration was considered as the treatment time. Mean arterial pressure (MAP), RPP, and RBF were measured for 5 min at the control or treat times. Renal vascular resistance (RVR) was calculated as the RPP/RBF ratio. The rats were sacrificed by the end of the experiments, and the kidney was removed and weighed immediately.

\section{Statistical analysis}

Data are expressed as mean \pm SEM. For baseline data, the parameters were compared between each group using t-Student test. For each individual gender, the MAP, RPP and RBF responses (the difference between control and $30 \mathrm{~min}$ after commencing vehicle or antagonist) to A779 (group 1) or vehicle (group 2) when AT1R and AT2R were blocked were compared using repeated measures ANOVA. The urine volumes between the two groups were compared using t-Student test. P values $<0.05$ were considered statistically significant.

\section{Results}

Baseline measurements (equilibrium or control stage)

MAP, RPP, RBF, and RBF/wet kidney tissue weight (RBF/KW) at the baseline measurement is shown in Table I. There were no significant differences between the two genders.

Table I: Mean baseline levels of systematic pressure and renal variables before vehicle or antagonist treatment in anaesthetised rats

\begin{tabular}{|c|c|c|c|c|}
\hline \multirow{2}{*}{$\begin{array}{c}\text { Group } \\
\text { Variable }\end{array}$} & \multicolumn{2}{|c|}{ Losartan + PD123319 + A779 } & \multicolumn{2}{|c|}{ Losartan + PD123319 + vehicle } \\
\hline & Male $(n=13)$ & Female $(n=10)$ & Male $(n=14)$ & Female $(n=12)$ \\
\hline MAP (mmHg) & $115.3 \pm 1.5$ & $109.6 \pm 2.6$ & $113.5 \pm 1.9$ & $113.5 \pm 1.9$ \\
\hline $\mathrm{RPP}\left(\mathrm{ml} \mathrm{min}{ }^{-1}\right)$ & $109.7 \pm 1.5$ & $102.8 \pm 2.7$ & $108.7 \pm 2.1$ & $107.5 \pm 2.7$ \\
\hline $\operatorname{RBF}\left(\mathrm{ml} \mathrm{min}{ }^{-1}\right)$ & $2.1 \pm 0.1$ & $2.2 \pm 0.1$ & $2.1 \pm 0.1$ & $2.0 \pm 0.1$ \\
\hline $\mathrm{RBF} / \mathrm{W}\left(\mathrm{ml} \mathrm{min} \mathrm{m}^{-1} \mathrm{~g}^{-1}\right.$ wet kidney wt) & $3.0 \pm 0.2$ & $3.1 \pm 0.2$ & $2.9 \pm 0.1$ & $2.8 \pm 0.1$ \\
\hline
\end{tabular}

Data are the mean \pm SEM. MAP, mean arterial pressure; RBF, renal blood flow; RBF/W, renal blood flow per gram wet kidney weight; RPP, renal perfusion pressures.

Responses to Mas receptor antagonist and vehicle when AT1R and AT2R were blocked Co-administration of losartan and PD123319 decreased MAP, RPP, and RVR significantly in both genders $(\mathrm{P}<0.0001)$ while RBF/KW increased statistically $(\mathrm{P}<0.01)$ (Fig. 1). These results were not altered when A779 was added to losartan and PD123319 infusion. However, in male rats, there was a tendency to an increase in $\mathrm{RBF} / \mathrm{KW}$ by infusion of $\mathrm{A} 779$ as compared to the vehicle $(\mathrm{P}=0.08)$. At the same time such finding in female rats was not observed (Fig. 1). The data for the urine volume during $30 \mathrm{~min}$ of antagonist (A779) or vehicle administration (when both Ang II receptors were blocked) is shown in Fig 2. A779 administration reduced the urine volume non-significantly. 
Male
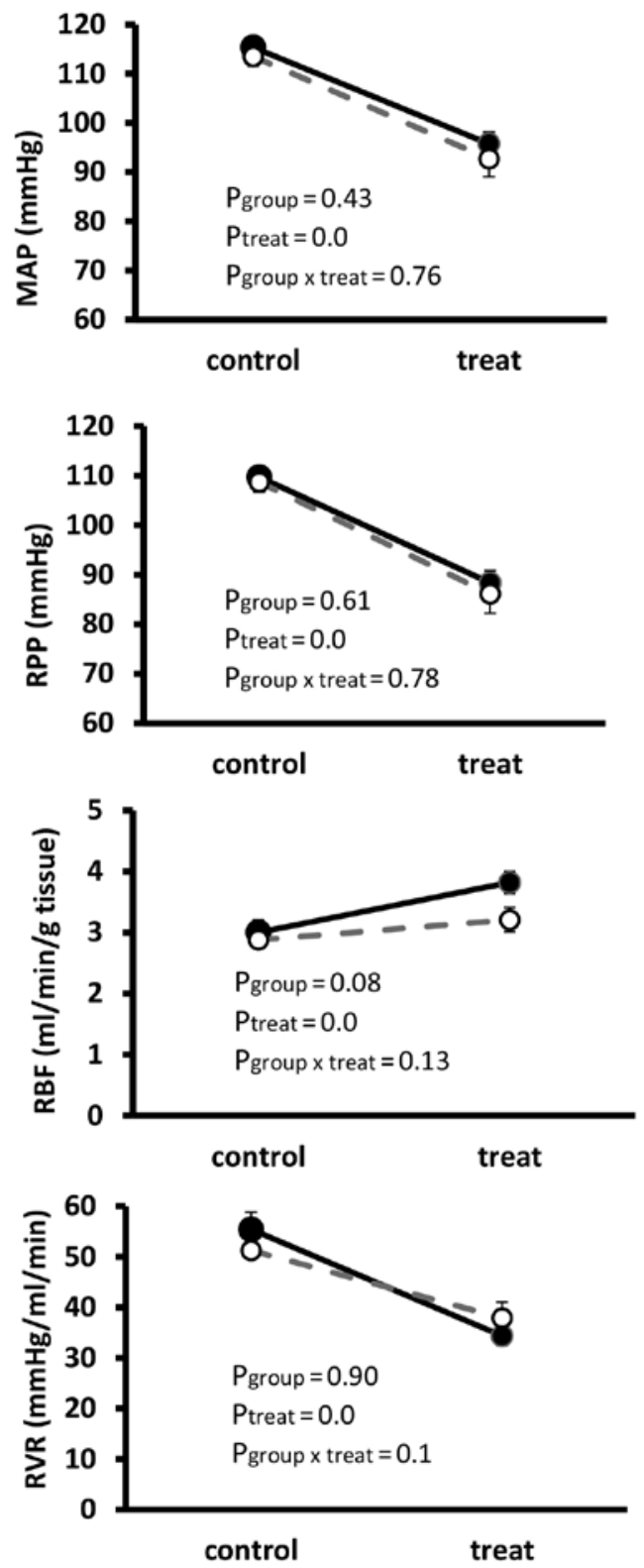

Female
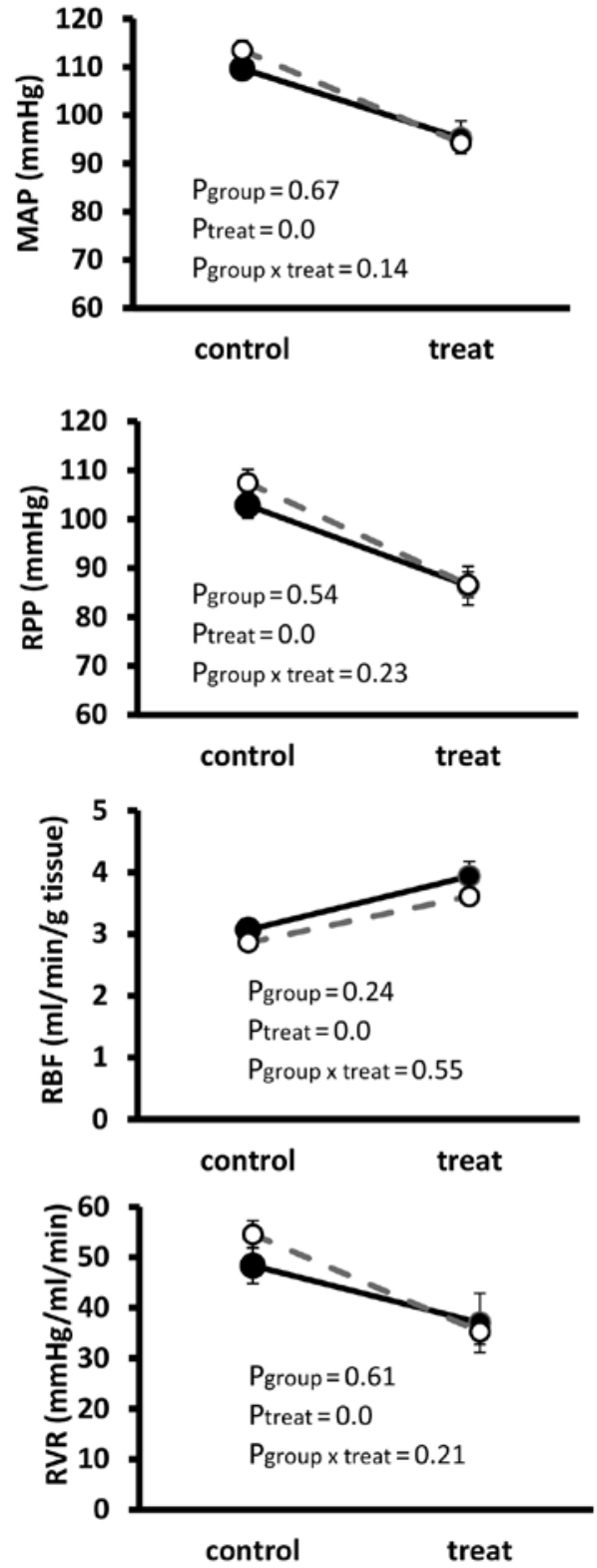

Fig. 1: Male and female rats' data.

Legend: Effect of vehicle and A779 accompanied with co-blockade of angiontensin II receptors type 1 and 2 on mean arterial and renal perfusion pressures (MAP and RPP), renal blood flow (RBF), RBF per g kidney weight $(\mathrm{RBF} / \mathrm{g}$ tissue) and renal vascular resistance (RVR). Data are presented as mean $\pm \mathrm{SEM}$. The data were compared between the groups using repeated measure ANOVA with factor group, time (control and treat)

and their interaction 
Male

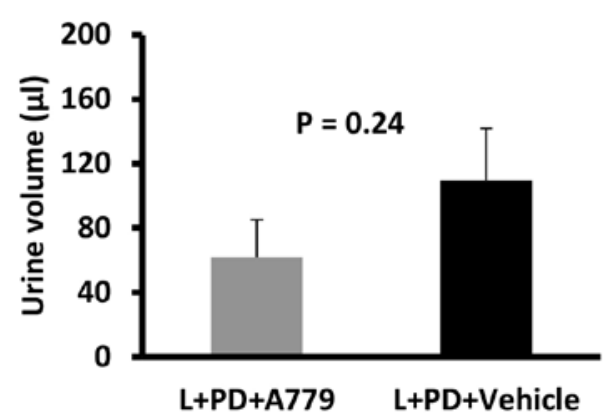

Female

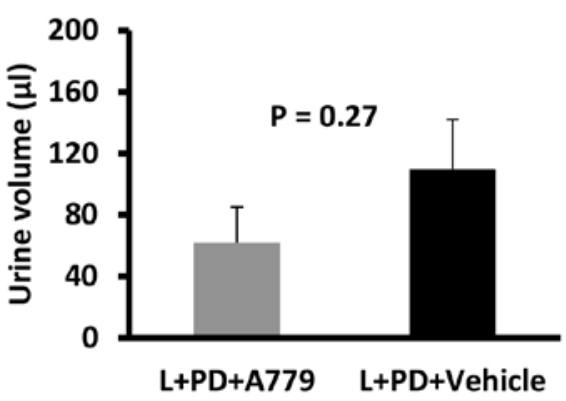

Fig. 2: The collected urine volume during $30 \mathrm{~min}$ of antagonist (A779) or vehicle administration when both Ang II receptors were blocked.

Legend: L and PD stand for losartan and PD123319, respectively.

Two groups were compared using t-Student test.

\section{Discussion}

The present study had two major findings. First, it was shown that in absence of AT1R and AT2R; MAP, RPP, and RVR decreased significantly in both genders, and no alteration by MasR antagonist could be recorded. Second, dual blockade of AT1R and AT2R increased $\mathrm{RBF}$ in male and female rats, but in male rats, there was a tendency to increase $\mathrm{RBF} / \mathrm{KW}$ by A779 as compared with the vehicle.

Chronic treatment with either ACE inhibitors or AT1R blockers increases plasma levels of Ang 1-7 (5-25-fold), Ang I and ACE2 activity (19, 43). However, increase in Ang 1-7 leads to vasodilatory effects due to production of nitric oxide (NO) (28), potentiation of endogenous bradykinin (39) and binding Ang 1-7 to ACE that facilities the crosstalk between ACE and bradykinin B2 receptor $(10,25,39)$. Furthermore, bradykinin receptor participates in Ang 1-7 effect $(15,30)$. Infusion of AT2R antagonist; PD123319 at 1, 10, and $100 \mathrm{mg} / \mathrm{kg} /$ min does not significantly affect either blood pressure or any parameter of renal hemodynamics measured (21). The dose of PD123319 in our study was $1 \mathrm{mg} / \mathrm{kg} / \mathrm{h}$, therefore, it was assumed that decrease in MAP, RPP, and RVR was not related to the PD123319. When Ang 1-7 and A779 were used at equimolar doses, Ang 1-7 antagonist failed to block Ang 1-7-induced depressor response against AT1R blockade; suggesting that Ang 1-7 may act via the AT2R (43). Therefore, there is a complex interaction between RAS receptors $(4,6)$, and some actions of Ang 1-7 may also be blocked by AT1R $(1,5)$ or AT2R antagonists $(9)$; suggesting a crosstalk between the MasR and Ang II receptors (20). Other data indicated that the antidiuretic effect of AVE0991 that mimics the effects of Ang 1-7 was completely blocked by PD123319 and partially blocked by losartan (43). Safari et al. showed that simultaneous administration of A779 and PD123319 did not significantly change the basal MAP, RBF, or RVR values in either sex, while A779 alone significantly reduced RBF in female but not in male (27). In a previous study, we found that impact of MasR on pressure natriuresis and diuresis was gender related, and in presence of MasR while AT1R and AT2R were blocked, pressure natriuresis and diuresis was augmented in male but not in female rats (22). Many putative mechanisms could participate in this interaction; including functional antagonism, 
crosstalk, or oligomerization (44), and other studies have explained the formation of heterodimers among different receptors $(2,35)$. There are static heterodimers between the AT1R and bradykinin $\mathrm{B}_{2}$ receptor, and between the AT1R and MasR that may increase activation of $\mathrm{G}$ protein $(4,16,24,35)$. Therefore, it is not possible to explain the exact mechanism related to the tendency to an increase in $\mathrm{RBF} / \mathrm{KW}$ by $\mathrm{A} 779$ in male rats.

\section{Conclusion}

In the absence of Ang II receptors; MAP, RPP, and RVR decreased gender and MasR independently. However, $\mathrm{RBF} / \mathrm{KW}$ increased in both genders, and in male rats, there was a tendency for the increase in RBF/KW by A779 as compared to vehicle. These results suggest a complex crosstalk between RAS receptors.

\section{Acknowledgements}

This research was supported by Isfahan University of Medical Sciences.

\section{Conflict of interest}

The authors have not a direct financial relation with the commercial identities mentioned in this article. So, the authors have no conflict of interests.

\section{REFERENCES}

1. Baracho N, Simões e Silva AC, Khosla M, Santos R: Effect of selective angiotensin antagonists on the antidiuresis produced by angiotensin-(1-7) in water-loaded rats. Braz. J. Med. Biol. Res. 31, 1221-1227 (1998)

2. Breitwieser GE: G protein-coupled receptor oligomerization implications for G protein activation and cell signaling. Circulation Research 94(1), 17-27 (2004)

3. Campbell DJ: The renin-angiotensin and the kallikrein-kinin systems. Int. J. Biochem. Cell Biol. 35, 784-791 (2003)

4. Canals M, Jenkins L, Kellett E, Milligan G: Up-regulation of the angiotensin II type 1 receptor by the MAS proto-oncogene is due to constitutive activation of Gq/G11 by MAS. J Biol. Chem. 281, 16757-16767 (2006)

5. Caruso-Neves C, Lara L, Rangel L, Grossi A, Lopes A: Angiotensin-(1-7) modulates the ouabain-insensitive $\mathrm{Na}+$-ATPase activity from basolateral membrane of the proximal tubule. Biochim. Biophys. Acta 1467, 189197 (2000)

6. Dahl TD, Hultstrom M, Iversen BM, Helle F: Adenosine sensitization after angiotensin II stimulation in afferent arterioles from normal rats does not occur during two-kidney, one-clip hypertension. Acta Physiol. (Oxf) 201, 289-294 (2011)

7. de Castro CH, dos Santos RAS, Ferreira AJ, Bader M, Alenina N, de Almeida AP: Evidence for a functional interaction of the angiotensin-(1-7) receptor Mas with AT1 and AT2 receptors in the mouse heart. Hypertension 46, 937-942 (2005)

8. De Mello WC, Danser AJ: Angiotensin II and the heart on the intracrine renin-angiotensin system. Hypertension 35, 1183-1188 (2000)

9. De Souza A, Lopes A, Pizzino C, Fossari R, Miguel N, Cardozo F: Angiotensin II and angiotensin-(1-7) inhibit the inner cortex $\mathrm{Na}^{+}$-ATPase activity through AT2 receptor. Regul. Pept. 120, 167-175 (2004)

10. Deddish PA, Marcic B, Jackman HL, Wang H-Z, Skidgel RA, Erdos EG: N-domain-specific substrate and C-domain inhibitors of angiotensin-converting enzyme angiotensin-(1-7) and keto-ACE. Hypertension 31, 912-917 (1998) 
11. Donoghue M, Hsieh F, Baronas E, Godbout K, Gosselin M, Stagliano N, et al: A novel angiotensin-converting enzyme-related carboxypeptidase (ACE2) converts angiotensin I to angiotensin 1-9. Circ. Res. 87, e1-e9 (2000)

12. Eriksson U, Danilczyk U, Penninger JM: Just the beginning: novel functions for angiotensin-converting enzymes. Curr. Biol. 12, R745-R752 (2002)

13. Evans RG, Majid DS, Eppel GA: Mechanisms mediating pressure natriuresis: what we know and what we need to find out. Clin. Exp. Pharmacol. Physiol. 32, 400-409 (2005)

14. Fakhouri F, Placier S, Ardaillou R, Dussaule JC, Chatziantoniou C: Angiotensin II activates collagen type I gene in the renal cortex and aorta of transgenic mice through interaction with endothelin and TGF-beta. J. Am. Soc. Nephrol. 12, 2701-2710 (2001)

15. Ferreira A, Santos R, Almeida A: Angiotensin-(1-7) improves the post-ischemic function in isolated perfused rat hearts. Braz. J. Med. Biol. Res. 35, 1083-1090 (2002)

16. Hansen JL, Hansen JT, Speerschneider T, Lyngsø, C, Erikstrup N, Burstein ES: Lack of evidence for AT1R/B2R heterodimerization in COS-7, HEK293, and NIH3T3 cells; how common is the AT1R/B2R heterodimer? J. Biol. Chem. 284, 1831-18399 (2009)

17. Hocht C, Mayer M, Taira CA: Therapeutic perspectives of angiotensin-(1-7) in the treatment of cardiovascular disease. Open Pharmacol. J. 3, 21-31 (2009)

18. Iusuf D, Henning RH, van Gilst WH, Roks AJ: Angiotensin-(1-7): pharmacological properties and pharmacotherapeutic perspectives. Eur. J. Pharmacol. 13, 585, 303-312 (2008)

19. Luque M, Martin P, Martell N, Fernandez C, Brosnihan KB, Ferrario CM: Effects of captopril related to increased levels of prostacyclin and angiotensin-(1-7) in essential hypertension. J. Hypertens. 14, 799-805 (1996)

20. Lyngso C, Erikstrup N, Hansen JL: Functional interactions between 7TM receptors in the renin-angiotensin system-dimerization or crosstalk? Mol. Cell. Endocrinol. 302, 203-212 (2009)

21. Macari D, Bottari S, Whitebread S, De Gasparo M, Levens N: Renal actions of the selective angiotensin AT2 receptor ligands CGP 42112B and PD 123319 in the sodium-depleted rat. E. J. Pharmacol. 249, 85-93 (1993)

22. Mansoori A, Oryan S, Nematbakhsh M: Role of Mas receptor antagonist (A779) on pressure diuresis and natriuresis and renal blood flow in the absence of angiotensin II receptors type 1 and 2 in female and male rats. J. Physiol. Pharmacol. 65, 633-639 (2014)

23. Pinheiro SVB, Simões e Silva AC: Angiotensin converting enzyme 2, angiotensin-(1-7), and receptor MAS axis in the kidney. Int. J. Hypertens. 2012, ID 414128 (2012)

24. Porrello ER, Pfleger KD, Seeber RM, Qian H, Oro C, Abogadie F: Heteromerization of angiotensin receptors changes trafficking and arrestin recruitment profiles. Cell Signal. 23, 1767-1776 (2011)

25. Prada J, Ferreira AJ, Katovich MJ, Shenoy V, Qi Y, Santos RA: Structure-based identification of small-molecule angiotensin-converting enzyme 2 activators as novel antihypertensive agents. Hypertension 51, 1312-1317 (2008)

26. Reckelhoff JF: Gender differences in the regulation of blood pressure. Hypertension 37, 1199-1208 (2001)

27. Safari T, Nematbakhsh M, Hilliard LM, Evans RG, Denton KM: Sex differences in the renal vascular response to angiotensin II involves the Mas receptor. Acta Physiol (Oxf) 206, 150-156 (2012)

28. Sampaio WO, Nascimento AAS, Santos RAS: Regulation of cardiovascular signaling by kinins and products of similar converting enzyme systems-systemic and regional hemodynamic effects of angiotensin-(1-7) in rats. Am. J. Phsiol. Heart Circ. Physiol. 284, H1985-H1994 (2003)

29. Sampson AK, Moritz KM, Denton KM: Postnatal ontogeny of angiotensin receptors and ACE2 in male and female rats. Gend. Med. 9, 21-32 (2012)

30. Santos RA, Campagnole-Santos MJ, Andrade S1P: Angiotensin-(1-7): an update. Regul. Pept. 91, 45-62 (2000)

31. Santos RA, Simões e Silva AC, Maric C, Silva DM, Machado RP, de Buhr I, Heringer-Walther S, Pinheiro SV, Lopes MT, Bader M, Mendes EP, Lemos VS, Campagnole-Santos MJ, Schultheiss HP, Speth R, Walther T: Angiotensin-(1-7) is an endogenous ligand for the G protein-coupled receptor Mas. Proc. Natl. Acad Sci. USA 100, 8258-8263 (2003)

32. Santos RA, Ferreira AJ, Simões e Silva AC: Recent advances in the angiotensin-converting enzyme 2-angiotensin (1-7)-Mas axis. Exp. Physiol. 93, 519-527 (2008)

33. Santos RA, Haibara AS, Campagnole-Santos MJ, Simões E Silva AC, Paula RD, Pinheiro SV: Scientific contributions-characterization of a new selective antagonist for angiotensin-(1-7), D-pro7-angiotensin-(1-7). Hypertension 41, 737-743 (2003)

34. Silbiger S, Neugarten J: Gender and human chronic renal disease. Gend. Med. 5 Suppl A, S3-S10 (2008) 
35. Silva-Antonialli MM, Tostes RC, Fernandes L, Fior-Chadi DR, Akamine EH, Carvalho MH: A lower ratio of AT1/AT2 receptors of angiotensin II is found in female than in male spontaneously hypertensive rats. Cardiovasc. Res. 62, 587-593 (2004)

36. Skeggs LT, Lentz KE, Kahn JR, Hochstrasser H: Kinetics of the reaction of renin with nine synthetic peptide substrates. J. Exp. Med. 128, 13-34 (1968)

37. Sullivan JC: Sex and the renin-angiotensin system: inequality between the sexes in response to RAS stimulation and inhibition. Am. J. Physiol. Regul. Integr. Comp. Physiol. 294, R1220-R1226 (2008)

38. Sullivan JC, Bhatia K, Yamamoto T, Elmarakby AA: Angiotensin (1-7) receptor antagonism equalizes angiotensin II-induced hypertension in male and female spontaneously hypertensive rats. Hypertension 56, $658-66(2010)$

39. Tom B, de Vries R, Saxena PR, Danser AJ: Bradykinin potentiation by angiotensin-(1-7) and ACE inhibitors correlates with ACE C- and N-domain blockade. Hypertension 38, 95-99 (2001)

40. Touyz RM, Schiffrin EL: Signal transduction mechanisms mediating the physiological and pathophysiological actions of angiotensin II in vascular smooth muscle cells. Pharmacol. Rev. 52, 639-672 (2000)

41. Tschope C, Schultheiss H-P, Walther T: Multiple interactions between the renin-angiotensin and the kallikreinkinin systems: role of ACE inhibition and AT1 receptor blockade. J. Cardiovasc. Pharmacol. 39, 478-487 (2002)

42. Vallon V, Heyne N, Richter K, Khosla MC, Fechter K: [7-D-ala]-angiotensin 1-7 blocks renal actions of angiotensin 1-7 in the anesthetized rat. J. Cardiovasc. Pharmacol. 32, 164-167 (1998)

43. Walters PE, Gaspari TA, Widdop RE: Angiotensin-(1-7) acts as a vasodepressor agent via angiotensin II type 2 receptors in conscious rats. Hypertension 45, 960-966 (2005)

44. Zhu Z, Zhong J, Zhu S, Liu D, van der Giet M, Tepel M: Angiotensin-(1-7) inhibits angiotensin II-induced signal transduction. J. Cardiovasc. Pharmacol. 40, 693-700 (2002)

45. Zhuo JL, Li XC: New insights and perspectives on intrarenal renin-angiotensin system: focus on intracrine/ intracellular angiotensin II. Peptides 32, 1551-1565 (2011) 